\title{
Prediktiv gentesting skal være til barnets beste
}

Vi tenker oss følgende situasjon: En seks år gammel jente får påvist trombocytopeni etter en uvanlig stor neseblødning. Som nyfødt hadde hun anemi og hyperbilirubinemi, og utskiftningstransfusjon ble vurdert. Hennes tre år gamle søster hadde mild forbigående trombocytopeni i forbindelse med en luftveisinfeksjon. Begge jentene og en yngre bror er alminnelig friske. Moren er 15 uker gravid. Foreldrene er friske. De har funnet frem til artikkelen om ADAMTS13assosiert kongenital trombotisk trombocytopenisk purpura av Anne Sophie von Krogh og medarbeidere (1) i dette nummer av Tidsskriftet og spør: Kan jentene våre ha denne sjeldne tilstanden? Skal sønnen vår testes for den? Og hva med det nye barnet når det blir født?

Økt blødningstendens og anemi ved ADAMTS13-assosiert kongenital trombotisk trombocytopenisk purpura kan manifestere seg i ulike livsfaser og vise stor variasjon i alvorlighetsgrad selv innen samme familie. Forebyggende behandling kan hindre organskade og i verste fall prematur død (1). Sykdommen er en sjelden årsak til trombocytopeni - men totalt sett er slike sjeldne genetiske sykdommer hyppige. McCandless og medarbeidere fant for eksempel en underliggende genetisk diagnose hos om lag én av tre som var innlagt på et stort barnesykehus i USA (2).

I lov om humanmedisinsk bruk av bioteknologi m.m. (bioteknologiloven) (3) defineres genetisk testing som «... alle typer analyser av menneskets arvestoff, både på nukleinsyre- og kromosomnivå, av genprodukter og deres funksjon, eller organundersøkelser, som har til hensikt å gi informasjon om menneskets arveegenskaper».

Jentenes sykdomsbilde kan passe med ADAMSTS13-assosiert kongenital trombotisk trombocytopenisk purpura. Genetisk testing av dem vil være diagnostisk og kan rekvireres av behandlende lege. Deres asymptomatiske bror og det nye barnet aktualiserer problemstillingen om prediktiv testing. Undersøkelse av friske barn for genetisk sykdomsdisposisjon, prediktiv testing, er også regulert av bioteknologiloven og forutsetter at familien først făr genetisk veiledning. Slik testing «... skal ikke utføres på barn før barnet er fylt 16 år, med mindre undersøkelsen kan påvise forhold som ved behandling kan forhindre eller redusere helseskade hos barnet».

Kombinasjonen av nye tester, stadig mer avanserte bioinformatiske verktøy og økende grad av internasjonalt samarbeid fører til at langt flere med sjeldne sykdommer nå får en årsaksdiagnose (4). Behandlingen er fortsatt oftest symptomatisk, men det finnes viktige unntak: Per i dag kjenner vi for eksempel til omkring 90 sjeldne medfødte stoffskiftesykdommer som affiserer hjernen hvor behandling rettet mot den patofysiologiske prosessen kan modifisere sykdomsforløpet, føre til mer presist tilpasset symptomatisk behandling eller i beste fall forhindre utviklingshemning (5). Føllings sykdom, eller fenylketonuri, er prototypen på en slik sykdom.

Prediktiv genetisk testing er indisert når resultatet påvirker den medisinske omsorgen for barnet. Det kan dreie seg om valg av medisinsk behandling eller oppstart eller avslutning av et overvåkningsregime. Hvis det dreier seg om en alvorlig sykdom som kan debutere tidlig og eventuelt behandles, er det fornuftig å teste barnet raskt. For sykdommer som kan debutere i nyfødtperioden, slik som for eksempel ADAMTS13-assosiert kongenital trombotisk trombocytopenisk purpura, kan en plan for testing avklares før barnet blir født. For sykdommer som debuterer senere i barneårene, kan tidspunktet for testing diskuteres med foreldrene. Barnet kan inkluderes i diskusjonen hvis det er modent nok (6).

Diagnosespesifikk oppfølging av friske barn er aktuelt for tilstander som for eksempel nevrofibromatose type 2, et syndrom som disponerer for utvikling av svulster i sentralnervesystemet. Når mor eller far har nevrofibromatose type 2, er det inntil $50 \%$ sannsynlighet for at hvert av barna arver den aktuelle genfeilen. Testing av et friskt barn kan hindre unødig bekymring for denne alvorlige sykdommen, og skal utføres før 10-12 års alder, da eventuell oppfølging hos spesialister skal begynne (7).

Hva med familien som ble beskrevet innledningsvis? Hvis mistanken om ADAMSTS13-assosiert kongenital trombotisk trombocytopenisk purpura bekreftes hos jentene, bør foreldrene få tilbud om genetisk veiledning ved en av landets avdelinger for medisinsk genetikk. Deres sønn og det nye barnet kan testes prediktivt fordi resultatet har behandlingsmessige konsekvenser i barneårene, slik det er beskrevet i oversiktsartikkelen (1). Testingen er rask, rimelig og sikker når familiens genfeil er kjent. Ved slike autosomalt recessivt arvelige sykdommer er det først og fremst søsknene til den syke som har økt sannsynlighet for å utvikle sykdommen - $25 \%$ ved fødselen. Hovedhensikten med genetisk veiledning i denne situasjonen er å understreke for foreldrene at de kan få det svaret de ikke ønsker seg - at ett av eller begge deres to andre barn er også disponert for å utvikle ADAMSTS13-assosiert trombotisk trombocytopenisk purpura. Finnes det andre par i slekten hvor både mor og far er i slekt med den syke, kan disse ha økt sannsynlighet for å få barn med sykdommen. Også de kan få tilbud om genetisk veiledning.

\section{Trine Prescott \\ tripre@sthf.no}

Trine Prescott (f. 1952) er spesialist i medisinsk genetikk og i barnesykdommer og overlege ved Seksjon for medisinsk genetikk, Avdeling for laboratoriemedisin, Sykehuset Telemark.

Forfatter har fylt ut ICMJE-skjemaet og oppgir ingen interessekonflikter.

\section{Litteratur}

1. von Krogh AS, Waage A, Quist-Paulsen P. Kongenital trombotisk trombocytopenisk purpura. Tidsskr Nor Legeforen 2016; 136: 1452-7.

2. McCandless SE, Brunger JW, Cassidy SB. The burden of genetic disease on inpatient care in a children's hospital. Am J Hum Genet 2004; 74: 121-7.

3. Lov om humanmedisinsk bruk av bioteknologi m.m. (bioteknologiloven). https://lovdata.no/dokument/NL/lov/2003-12-05-100/ (22.8.2016).

4. Wright CF, Fitzgerald TW, Jones WD et al. Genetic diagnosis of developmental disorders in the DDD study: a scalable analysis of genome-wide research data. Lancet 2015: 385: 1305-14

5. Tarailo-Graovac M, Shyr C, Ross CJ et al. Exome sequencing and the management of neurometabolic disorders. N Engl J Med 2016; 374: 2246-55.

6. Borry P. Evers-Kiebooms G, Cornel MC et al. Genetic testing in asymptomatic minors: background considerations towards ESHG Recommendations. Eur J Hum Genet 2009: 17: 711-9.

7. Evans DG, Neurofibromatosis I, Pagon RA et al. red. GeneReviews. Oppdatert 18.8.2011. www.ncbi.nlm.nih.gov/pubmed/20301380 (22.8.2016). 